\title{
Environmental and Health Impact of Solid Waste Disposal in Umuahia and Environs, Southeast, Nigeria
}

\author{
${ }^{1}$ NDUKWE, VA; $*{ }^{1}$ UZOEGBU, MU; ${ }^{2}$ NDUKWE, OS; ${ }^{2}$ AGIBE, AN \\ ${ }^{*}$ Department of Geology, University of Port Harcourt, Port Harcourt, Nigeria. \\ ${ }^{2}$ Department of Geology, Federal University, Oye-Ekiti, Ekiti State, Nigeria. \\ *Corresponding Author Email: uche.uzoegbu@uniport.edu.ng; Tel: 08030715958
}

\begin{abstract}
Indiscriminate disposal of solid waste in dumpsites located within urban areas has proved to be a problem to nearby residents in most developing cities of the world, Umuahia is no exception. Open dumps have environmental safeguards; they can pose major public health threats and environmental effects in urban cities. Therefore, this paper presents the findings of a research carried out in Umuahia municipal area in Abia State to determine the environmental and health impacts of solid waste disposal at Umuahia gate, Upstair line, Ahia Eke, New Timber gate, Government College first gate, etc dumpsites on the surrounding human settlements and markets. Data were collected from nearby dumpsite household residents less than $30 \mathrm{~m}$ and far away household residents greater than $30 \mathrm{~m}$ through interviews and personal observations were used to collect some of the data. Descriptive statistics involving tables, graphs and figures were used to present and analyze the data. The educational level of respondents of nearby residents (NBR) ranges from 53.00 to 205.00 with total of 398 and far away residents (FAR) are between 53.00 and 110.00 with total of 233.00. The percentage for primary level, high education and not education is $39.60 \%, 16.80 \%$ and $43.60 \%$ respectively. The disposal methods used by respondents ranges from 35.00 to 128.00 with percentage between 9.00 to 32.00 for NBR and 23.00 to 85.00 with $10.00 \%$ to $36.00 \%$ for FAR. Results show that both NBR and FAR suffered from related diseases such as malaria, chest pains, diarrhea and cholera, due to the location of the dumpsite closer to their settlements.
\end{abstract}

\section{DOI:https://dx.doi.org/10.4314/jasem.v23i9.1}

Copyright: Copyright $(\mathrm{C} 2019$ Ndukwe et al. This is an open access article distributed under the Creative Commons Attribution License (CCL), which permits unrestricted use, distribution, and reproduction in any medium, provided the original work is properly cited.

Dates: Received: 27July 2019; Revised: 20 August 2019; 24August 2019

Keywords: Environment; Health; Solid Waste Disposal; Dumpsite

Open dumpsite approach as solid waste disposal method is a primitive stage of solid waste management in many parts of the world. It is one of the most poorly rendered services by municipal authorities in developing countries as the systems applied are unscientific, outdated and in- efficient. Solid waste disposal sites are found both within and on the outskirts of developing urban cities. With increase in the global population and the rising demand for food and other essentials, there has been a rise in the amount of waste being generated daily by each household (Foday et al., 2013). This waste is ultimately thrown into municipal disposal sites and due to poor and ineffective management, the dumpsites turn to sources of environmental and health hazards to people living in the vicinity of such dumps. One of the main aspects of concern is the pollution caused to the earth; be it land, air and water. According to Nguyen et al. (2011) many cities in developing countries face serious environmental degradation and health risks due to the weakly developed municipal solid waste management system. Several studies have been conducted in order to examine the health and environmental effects arising from waste dumps. Such studies showed that a link exists between the two (Aatamila et al., 2010; Giusti, 2009; Nwanta and Ezenduka, 2010; Xiao et al., 2007; Yongsi et al., 2008). The conclusion from this and other studies has led to an increasing interest of researchers in the study relating to environmental pollution as well as its effects on plants and animals. Few of these studies examined the environmental and health implications of solid waste disposal to people living in close proximity of wastes dumpsites (Boardi and Kuitunen, 2005; Forastiera et al., 2011; Gouveia and do Prado, 2009; Nabegu, 2010). The everincreasing consumption of resources results in huge amounts of solid wastes from industrial and domestic activities, which pose significant threats to human health (Foday et al., 2013; Frosch, 1996). However, the ills of inappropriately disposed municipal solid wastes are quite numerous to be mentioned. Health deterioration, accidents, flood occurrences, and environ-mental pressures are just a few of the negative effects. In many developing countries, solid waste disposal sites are found on the outskirts of urban areas. These areas become children's sources of contamination due to the incubation and proliferation of flies, mosquitoes, and rodents. They, in turn, are 
disease transmitters that affect population's health, which has its organic defenses in a formative and creative state. The said situation produces gastrointestinal, dermatological, respiratory, genetic, and several other kind of infectious diseases (Foday et al., 2013; Salam, 2010). Open dumpsites in developing urban cities involve in- discriminate disposal of waste. They are uncontrolled and therefore pose major health threats which affect the landscape of urban cities (Sood, 2004). The UNEPA (2006) stated that wastes that are not managed properly, especially solid waste from households and the community, are a serious health hazard and lead to the spread of infectious diseases. The report further stated that unattended wastes lying around attract flies, rats, and other creatures that, in turn, spread diseases. Normally, it is the wet waste that de- composes and releases a bad odor. The bad odor affects the people settled next to the dumpsite, which shows that the dumpsites have serious effects to people settled around or next to them. The group at risk from this un- scientific disposal of solid waste includes-the population in areas where there is no proper waste disposal method, especially the pre-school children, waste workers and workers in facilities producing toxic and infectious materials. Other high-risk group includes population living close to the waste dump (Aatamila et al., 2010; Foday et al., 2013). In particular, organic domes- tic waste poses a serious threat, since they ferment creating conditions favorable to the survival and growth of microbial pathogens. Direct handling of solid waste can result in various types of infectious and chronic diseases with the waste workers and rag pickers being the most vulnerable (Foday et al., 2013; Nwanta and Ezenduka, 2010). Studies conducted by Yongsi et al. (2008) show that exposure to hazardous waste in dumpsites can affect human health, children being the most vulnerable to these pollutants. Direct exposure can lead to diseases through chemical exposure as the release of chemical waste into the environment leads to chemical poisoning. Rushton (2003) in his studies to establish a connection between health and hazardous waste showed that waste from agriculture and industries can also cause serious health risks. Other than this, co-disposal of industrial waste with municipal waste can expose people to chemical and radioactive hazards. Health care waste and other medical waste disposed in dumpsites, mixed with domestic waste, increasing the risk of infection with Hepatitis B and HIV, and other related diseases (World Bank, 2005). Open dumpsites are a major problem to the environment especially to the air that we inhale. Dumpsites emit obnoxious odors and smoke that cause illness to people living in, around, or closer to them (Marshal, 1996). According to Medina (2002), pollution, a major environmental effect of dumpsites, is not directlytransferred from land to people, except in the case of dusts and direct contact with toxic materials. Pollutants deposited on land usually enter the human body through the medium of contaminated crops, animals, food products, or water. Also, the dumpsite has smelly and unsightly conditions. These conditions are worse in the summer because of extreme temperatures, which speed up the rate of bacterial action on biodegradable organic material. Disposal sites can also create health hazards for the neighborhood (Boardi and Kuitunen, 2005; Foday et al., 2013). Gouveia and Ruscitto (2009) highlighted that in a number of health surveys a wide range of health problems, including respiratory systems, irritation of the skin, eyes and nose, gastrointestinal problems, psychological disorders, and allergies, have been discovered. In addition, dumpsites closer to residential areas are always feeding places for dogs and cats. These pets, together with rodents, carry diseases with them to nearby homesteads. The objective of this paper is to determine the environmental and health impact of solid waste disposal at Umuahia gate, Upstair line, Ahia Eke, New Timber gate, Government College first gate, etc dumpsites on its surrounding human settlements.

\section{MATERIALS AND METHODS}

The study location lies within the Umuahia urban area at latitudes $5^{\circ} 26^{\prime}$ to $5^{\circ} 37^{\prime} \mathrm{N}$ and longitudes $7^{\circ} 24^{\prime}$ to $7^{\circ} 35^{\prime} \mathrm{E}$ (Fig. 1). The study is aimed at identifying the environmental and health impact of solid waste disposal on the human settlements around the dumpsites.

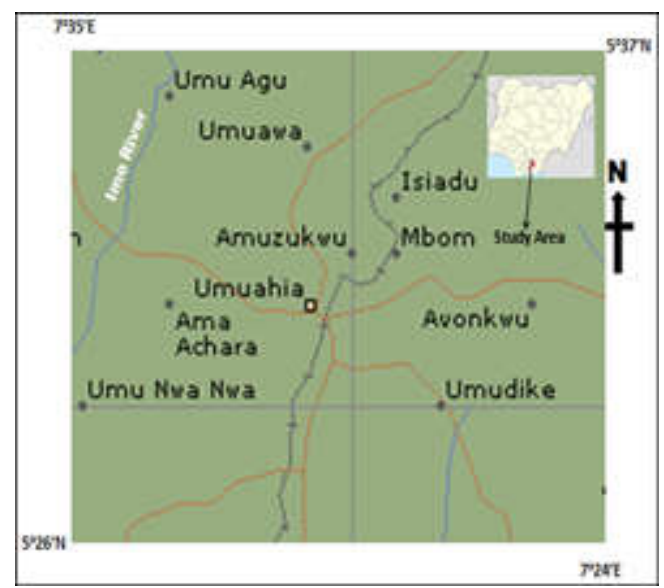

Fig. 1: Map showing location of the study area (Abia State)

We collected the data for this study from both primary and secondary sources to present the findings on the environmental and health impacts caused by solid waste disposal at dumpsites in Umuahia area of Abia State. Firstly, we involved a desk study of secondary data wherein documents and records relating to 
appropriate data sources including books, journals, newspapers, and activities both published and unpublished were studied to obtain background information on the environmental and health impacts of solid waste disposal at dumpsites in Umuahia area of Abia State; secondly, we visited the dumpsite where a few people involved in scavenging and selling of agricultural products were interviewed at random. Household residents in the surroundings of the dumpsites were also interviewed. Information obtained was used to update the data collected during the desk study. The obtained data on socioeconomic characteristics such as educational level and employment status and the obtained information on residents' views on the location of the dumpsites and their surroundings, disposal methods used by residents were used to determine the implications of the dumpsite to the health of the residents' community. Umuahia urban area was selected as a case study because it is the capital city of Abia State, a small state in Southeastern Nigeria. It is a major city on the Southeastern region with Aba a commercial city located on coordinates latitudes $4^{0} 40^{\prime}$ and $6^{0} 14^{\prime} \mathrm{N}$, and longitudes $7^{0} 10^{\prime}$ and $8^{0} 00^{\prime} \mathrm{E}$ with a total area of $5,243.7$ square kilometers in the eastern area of the country. The climate of Abia State is tropical (hot and humid); with the raining season lasting from May to December and the dry season from December to April, and rainfall along the can reach $495 \mathrm{~cm}$ a year with Umuahia having the highest amount of rainfall, greater than 3500 milliliters. It has a population of 2,833,999 (Statistics, National Population Commission, 2006). The city is the economic, financial and cultural centre of Abia State. All wastes disposed of in the dumpsite will end up there causing health risk and environmental disaster like massive flooding during the rains to the inhabitants (Foday et al., 2013; Gogra et al., 2010). In Umuahia, the Umuahia gate, Upstair line, Ahia Eke, Government College Umuahia dumpsites are now in the centre of the city, surrounded by many human settlements; thus posing public health hazards to residents who settle next to it. At the same time, the dumpsite is already filled; having been pushed beyond it limits, and due to poor operational system, the dumpsite has almost degraded into potentially hazardous and toxic dumps (Figs 2, 3, 4, 5, 6). Land is now scarce in the city to relocate the dumpsite; land owners in the surrounding villages and towns of the city are not ready to give up their lands for the creation of a new dumpsite. Therefore, as a best option, the location of the dumpsite should be properly planned and managed to avoid risks to human health and the environment, at large (Chander and Marc, 2006; Foday et al., 2013). Corrective and management measures are likely to be expensive, complex and pose serious threats to the environment and its inhabitants.

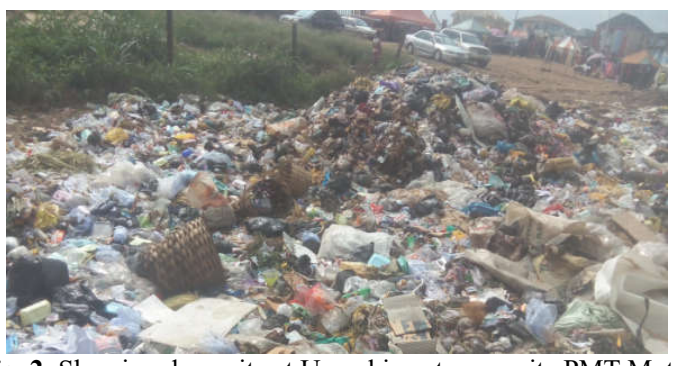

Fig. 2: Showing dumpsite at Umuahia gate opposite PMT Motor Park

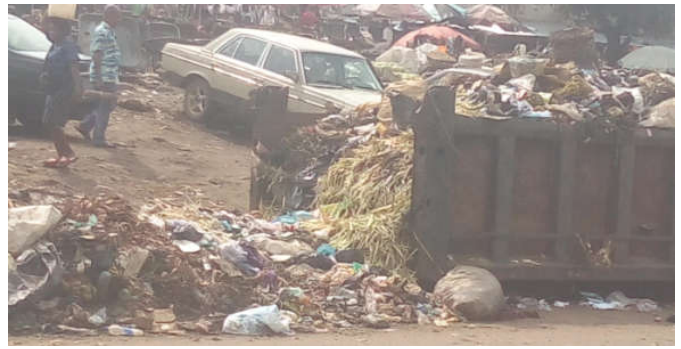

Fig. 3: Dumpsite at Umuahia gate along Amuzukwu Road

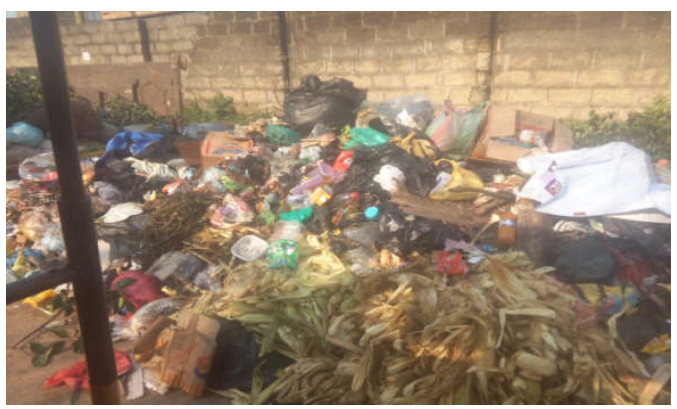

Fig. 4: Dumpsite atUpstair line along Agbama Road

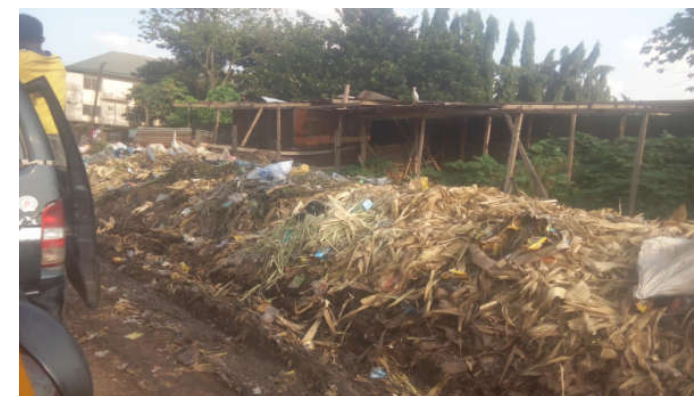

Fig. 5: Dumpsite at Ahia Eke along Umuahia - IkotEkpene Road

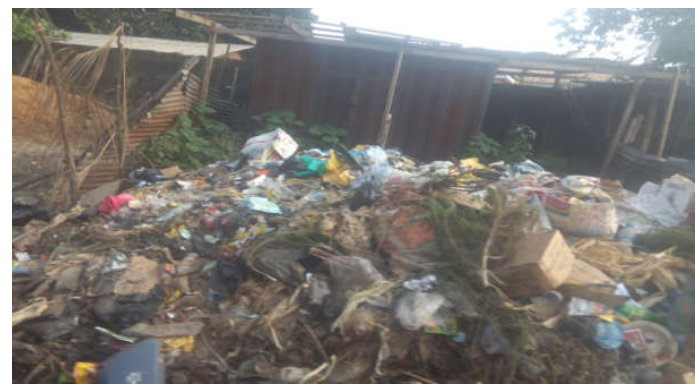

Fig. 6: Dumpsite at Government College, Umuahia along Umuahia - Ikot Ekpene Road 


\section{RESULTS AND DISCUSSION}

The Relationship between Socioeconomic Characteristics of Respondents and Environmental and Health Impact of Solid Waste Disposal: We studied two socioeconomic characteristics of respondents in this paper-employment status and educational level of respondents. This is probably because employment as a source of income may depend on the level of education. Figure 7shows data obtained on the employment status of respondents during field work. Majority of the respondents were not employed (48\%), making life difficult for them. Therefore, they embark on small scale agricultural petty trading in the area by the fringes of the dumpsites as a source of income and livelihood.

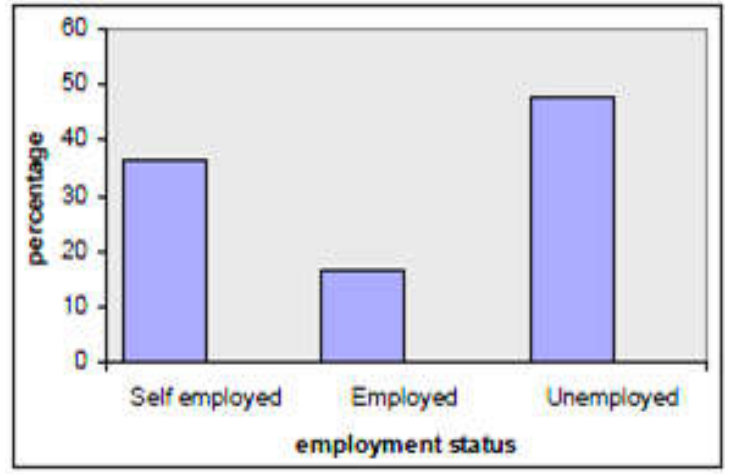

Fig. 7: Employment status of respondents.

These activities expose these residents to solid waste particularly hazardous wastes which can lead to various diseases through chemical exposure (Foday et $a l ., 2013)$. A majority of nearby residents (NBR) and far away residents (FAR) are not educated (Table 1).
Equally, a small percentage (16.8\%) indicated that they attained higher education. The scenario here is that majority of the respondents became scavengers in order to make a living from the collection of wastes. They collect cans, metallic objects, plastics and other products in order to sell them and make their living. Direct handling of solid waste, especially Health care waste mixed with domestic waste can lead to increasing risk of infection on scavengers.

Residents' Views on the Location of the Dumpsite and Their Surroundings: Household residents, especially those who are closer to the dumpsite are not happy about the location of the dumpsite in their community. They complained that the dumpsite is too close to their houses causing them a lot of sicknesses. Furthermore, they argued that their surroundings are smelly and filthy (Fig. 8) and some of the wastes from the dumpsite overlap their houses causing pollution in the environment.

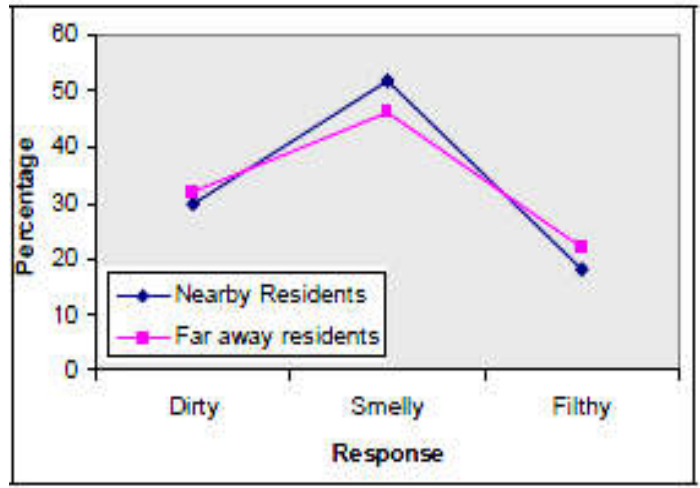

Fig. 8: Cleanliness of household residents' surrounding.

Table 1: Educational levels of respondents.

\begin{tabular}{lllll}
\hline Educational Level & \multicolumn{2}{l}{ Frequency } & Total & Percentage \\
\hline & Nearby Residents & Far away Residents & \\
Primary level & 140.00 & 110.00 & 250.00 & 396.00 \\
Higher education & 53.00 & 53.00 & 106.00 & 16.80 \\
Not education & 205.00 & 70.00 & 275.00 & 43.60 \\
Total & 398.00 & 233.00 & 631.00 & 100.00 \\
\hline
\end{tabular}

Table 2: Disposal methods used by respondents.

\begin{tabular}{lllll}
\hline Educational Level & $\begin{array}{l}\text { Nearby residents } \\
\text { Frequency }\end{array}$ & $\mathbf{\%}$ & $\begin{array}{l}\text { Far away residents } \\
\text { Frequency }\end{array}$ & $\mathbf{\%}$ \\
\hline Street bins & 35.00 & 9.00 & 23.00 & 10.00 \\
Dumpsite & 128.00 & 32.00 & 85.00 & 36.00 \\
Bury \& burn in pits & 62.00 & 16.00 & 30.00 & 13.00 \\
In bags from ASEPA & 56.00 & 14.00 & 25.00 & 11.00 \\
In drains \& streets & 117.00 & 29.00 & 70.00 & 30.00 \\
Total & 398.00 & 100.00 & 233.00 & 100.00 \\
\hline
\end{tabular}

Disposal Methods Used by Residents: The disposal methods of solid waste used by residents in the study area were very unsatisfactory. The preference of educated people to adopt better methods of waste disposal could be higher than illiterates (Table 2).
It is obvious from the table that most of the people who throw refuse on open land and drains are uneducated. Those who keep waste in bins or burn it are most likely those with higher education. In general, majority of the respondents either throw their waste on land or drains 
or streets. Equally, only a small proportion (21\%) of the respondents deposits their waste in bins and bags from Abia State Environmental Protection Agency (ASEPA) where they can be transferred to the designated points for ultimate disposal.

Impact of Having a Dumpsite in a Nearby Community: The dumpsite in a nearby community has many impacts as indicated by the respondents during the study. Majority of both nearby and far away residents indicated that the dumpsite is the breeding place for disease vectors, cause diseases, and makes the place dirty. However, the location of the dumpsite has considerably made the residents to suffer from various diseases with malaria being the most prevalent (Fig. 9)

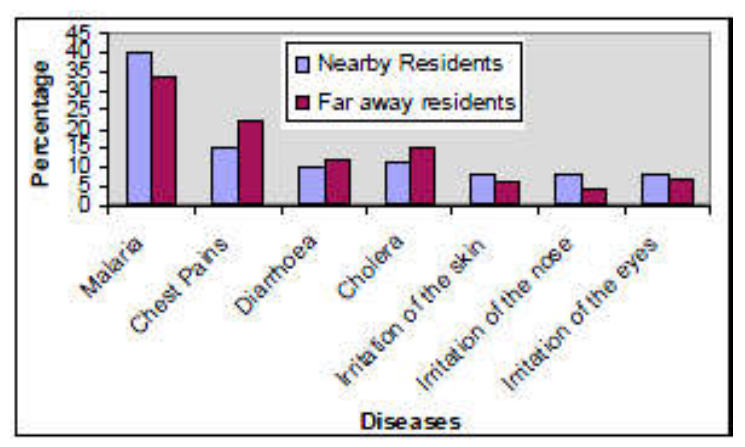

Fig. 9: Diseases due to the location of the dumpsite.

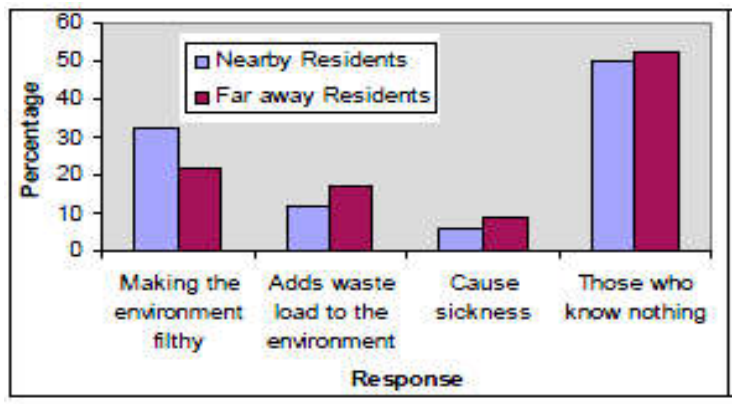

Fig. 10: Household residents' knowledge on pollution.

Measures Employed to Protect Household Residents from the Effects of the Dumpsite: All the respondents indicated that no measures are taken up to make sure that the community, at large, is protected from the dumpsite. Lack of protection from dumpsite related effects was worst because of low knowledge on pollution (Foday et al., 2013). Majority of both nearby residents and far away residents indicated that they knew nothing about pollution (Fig. 10). A small percentage of them indicated that pollution causes sickness. Therefore, the residents suggested that among many other options, the dumpsite should be relocated as an interim measure (Fig. 11). This is because the only source of information on pollution available to them is the media (Fig. 12) with its characteristic short comings such as affordability, frequent blackouts to name a few.

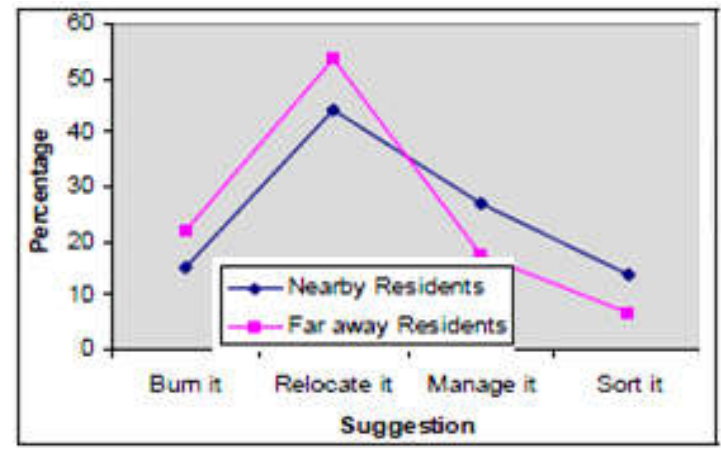

Fig. 11: Household suggestions on solid waste

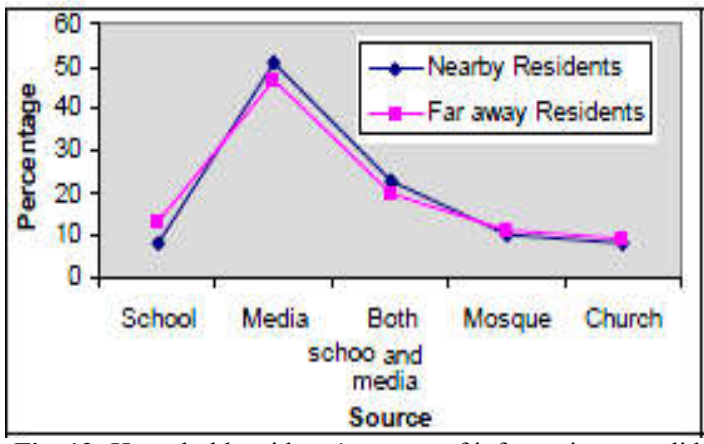

Fig. 12: Household residents' sources of information on solid waste management.

Conclusion: The study therefore, concludes that the dumpsite should be properly located and managed to minimize its effects on the environment. For improved health status of the populace living less than $30 \mathrm{~m}$ away from the dumpsites, it is a matter of must for the Umuahia Urban Development Council to resettle such persons. In the long term, efforts to provide low cost houses situated in a clean environment is a priority that the City Council must pursue vigorously to enable the poor to live in affordable yet clean environment. People need to be educated by health motivators about the effects of dump- sites on their health.

\section{REFERENCES}

Aatamila, M; Verkasalo, PK; Korhonen, MJ; Viluksela, MK; Pasanen, K; Tiittanen, P; Nevalainen, A (2010). "Odor Annoyance near Waste Treatment Centres: A Population-Based Study in Finland," J. Air Waste Mgt. Assoc., 60(4): 412-418.

Boardi, KO; Kuitunen, M (2005). "Environmental and Health Impacts of Household Solid Waste Handling and Disposal Practices in the Third World Cities: The Case of Accra Metropolitan Area, Ghana".J. Environ. Health, 68(4): 34-36. 
Chander, RR; Marc, R (2006). "Urban Infilling Impacts on Solid Waste Facilities," 2006. http://www.foreter.net/mw-0506-urban.html

Foday, PS; Xiangbin, Y; Quangyen, T (2013). Environmental and Health Impact of Solid Waste Disposal in Developing Cities: A Case Study of Granville Brook Dumpsite, Freetown, Sierra Leone.J. Env'tal Prot., 4: 665-670.

Forastiere, F; Badaloni, C; de Hoogh, K; von Kraus, MK; Martuzzi, M; Mitis, F; Palkovicova, L; Porta, D; Preiss, P; Ranzi, A; Perucci, CA; Briggs, D (2011). "Health Impact Assessment of Waste Management Facilities in Three European Countries," J. Env'tal Health, 10:p. 53.

Frosch, RA (1996). "Toward the End of Waste: Reflections on a New Ecology for Industry," Daedalus, 125(3):199-212.

Giusti, L (2009). "A Review of Waste Management Practices and Their Impact on Human Health," Waste Mgt., 29(8):2227-2239.

Gogra, AB; Yao, J; Kabba, VTS; Sandy, EH; Zaray, G; Gbanie, SP; Bandagba, TS (2010). "A Situational Analysis of Waste Management in Freetown, Sierra Leone," J. Amer. Sci., 6(5): 124135.

Gouveia, N; do Prado, RR (2009). "Health Risks in Areas Close to Urban Solid Waste Landfill Sites," Revista de SaúdePública, 44(5): 1-8.

Marshal, E (1995). "Analytical Study to Evaluate Associations between Dumpsites and Birth Effects," ATSDR CO.LTD, Atlanta, 1995.

Medina, M (2002). “Globalization, Development and Municipal Solid Waste Management in Third World Countries, Tijuana. Mexico: E1 Colegio de la Frontera," 2002. http://www.gdnet.org/pdf/2002AwardsMedalsWi nners/outstandingResearchDevelopment/martinm edinaMaetinezpa per.pdf

Nabegu, AB (2010). "An Analysis of Municipal Solid Waste in Kano Metropolis," J. Human Ecol., 31(2): 111-119.

Nguyen, PT; Matsui, Y; Fujiwara, T (2011). "Assessment of Plastics Waste Generation and Its Potential Recycling of Household Waste in Can
Tho City, Vietnam," Env'tal. Moni. Asoc 175(14):23-35.

Nwanta, JA; Ezenduka, E (2010). "Analysis of Nsukka Metropolitan Abattoir Solid Waste in South Eastern Nigeria: Public Health Implications," Archives of Environmental and Occupational Health, 65(1): 21- 26.

Rushton, L (2003). "Health Hazards and Waste Management," British Medical Bulletin, 68(1): 183- 197.

Salam, A (2010). "Environmental and Health Impact of Solid Waste Disposal at Mangwaneni Dumpsite in Manzini: Swaziland," J. Sust. Dev. Afri., 12(7): 23-45.

Sood, D (2004). "Solid Waste Management Study for Freetown (Component Design for World Bank, Draft Report Project No. P078389)," Great Falls, Virginia, 2004.

Statistics, National Population Commission (2006). "Population and Housing Census Final Results," 2006.

United Nations Environment Program Agency (UNEPA) (2006). "Informal Solid Waste Management." http://www.unep.org?PDF/Kenyawastemngntsect or/chapter1.pdf

World Bank (2005). "Waste Management in China: Issues and Recommendations," East Asia Infrastructure

Development.http://www.sciencedirect.com/scien ce/_ob=RedirectURL\&_method=externalObjLink \&_locator $=$ url\&_issn $=092 \mathrm{~B} \&$ targetURL $=$ http:\% $253 \% 252 \% 252 \%$ go.worldbank.org\%252F2HOV M07ZGO

Xiao, Y; Bai, X; Ouyang, Z; Zheng, H;Xing, F (2007). "The Composition, Trend and Impact of Urban Solid Waste in Beijing," Env'talMoni. Assoc. 135(1-3):21-30.

Yongsi, HBN; Herrmann, TM; Ntetu, AL; Sietchiping, R; Bryant, C (2008). "Environmental Sanitation and Health Risks in Tropical Urban Settings: Case study of Household Refuse and Diarrhea in Yaoundé-Cameroon," Int. J. Human Soc. Sci., 3(3): 220-228. 